\title{
Changes in mangrove vegetation area and character in a war and land use change affected region of Vietnam (Mui Ca Mau) over six decades
}

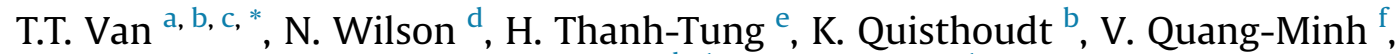 \\ L. Xuan-Tuan ${ }^{g}$, F. Dahdouh-Guebas ${ }^{\text {a, b, }}{ }^{1}$, N. Koedam ${ }^{\text {a, }}{ }^{1}$ \\ a Laboratory of Plant Biology and Nature Management, Vrije Universiteit Brussel-VUB, Brussels, Belgium \\ ${ }^{\mathrm{b}}$ Laboratory of Systems Ecology and Resource Management, Université Libre de Bruxelles-ULB, Brussels, Belgium \\ ${ }^{\mathrm{c}}$ Center for HydroMet and Climate Change, Vietnam Institute of Meteorology, Hydrology and Climate Change-IMHEN, Hanoi, Viet Nam \\ ${ }^{\mathrm{d}}$ Centre for Sustainable Rural Development, Hanoi, Viet Nam \\ e Division of Remote Sensing and GIS, Vietnam Institute of Meteorology, Hydrology and Climate Change -IMHEN, Hanoi, Viet Nam \\ ${ }^{\mathrm{f}}$ Department of Land Resources, College of Environment and Natural Resources, Can Tho University-CTU, Can Tho, Viet Nam \\ ${ }^{\mathrm{g}}$ Mangrove Ecosystem Research Centre, Hanoi National University of Education-HNUE, Hanoi, Viet Nam
}

\section{A R T I C L E I N F O}

\section{Article history:}

Received 10 December 2013

Received in revised form

27 November 2014

Accepted 28 November 2014

Available online 8 December 2014

\section{Keywords:}

Mangrove

Land cover change

War

Mangrove-shrimp farm

Mui Ca Mau

GIS

\begin{abstract}
A B S T R A C T
Aerial photographs and satellite images have been used to determine land cover changes during the period 1953 to 2011 in the Mui Ca Mau, Vietnam, especially in relation to changes in the mangrove area. The mangrove area declined drastically from approximately 71,345 ha in 1953 to 33,083 ha in 1992, then rose to 46,712 ha in 2011 . Loss due to herbicide attacks during the Vietnam War, overexploitation, and conversion into agriculture and aquaculture encouraged by land management policies are being partially counteracted by natural regeneration and replanting, especially a gradual increase in plantations as part of integrated mangrove-shrimp farming systems. The nature of the mangrove vegetation has markedly been transformed over this period. The results are valuable for management planning to understand and improve the contribution of mangrove forests to the provision of ecosystem services and resources, local livelihood and global interest.
\end{abstract}

(c) 2014 Elsevier Masson SAS. All rights reserved.

\section{Introduction}

Mangrove forests cover an estimated $152,361,000$ ha of the tropical and subtropical shorelines of the world (Spalding et al., 2010) and deliver important ecosystem functions, goods and services (Kathiresan, 2012; Lee et al., 2014). They form nursery grounds for numerous fish and shellfish (Lee et al., 2014); provide habitat for a diversity of birds, other vertebrates and invertebrates (Valiela et al., 2001; Nagelkerken et al., 2008; Cannicci et al., 2008); intercept land-derived nutrients, pollutants, and suspended matter before these contaminants reach deeper water (Semesi and Howell, 1992; Marshall, 1994; Rivera-Monroy and Twilley, 1996; Tam and Wong, 1999); and export material that support near-shore food webs (Kathiresan, 2012; Lee et al., 2014). Economically, mangrove

\footnotetext{
* Corresponding author.

E-mail address: ttran1@vub.ac.be (T.T. Van).

1 These authors contributed equally to this work.
}

ecosystems serve as a source of important products for livelihoods in coastal areas, such as poles and timber for building material and firewood, salt, tannins, dyes, charcoal and food (Abuodha and Kairo, 2001; FAO, 2007; Nfotabong-Atheull et al., 2009; Kathiresan, 2012).

Mangroves systems also play an important role in coastal stabilization and protection (Mazda et al., 1997, 2002; DahdouhGuebas and Pulukkuttige, 2009; Mukherjee et al., 2010; Kathiresan, 2012; Lee et al., 2014). Therefore, any loss of mangrove forest means a loss of subsistence and cash-based livelihoods and ecological and conservation function (Valiela et al., 2001). However, between 1980 and 2005, the world-wide mangrove forest area declined by 3.6 million ha (about $20 \%$ of the total area) (Spalding et al., 2010). Duke et al. (2007) indicated that a world without substantial areas of mangroves is a realistic forecast if the current destruction rate of mangrove ecosystems continues.

At a global level, natural and anthropogenic drivers of mangrove destruction and degradation include sea-level rise (Di Nitto et al., 2008, 2014); the harvest of forest products for local (wood, charcoal, and tannins) and industrial (woodchips and lumber) 
consumption (Ong, 1982; Abuodha and Kairo, 2001; Goessens et al., 2014); conversion of mangrove forest into agricultural, aquacultural, industrial and urban areas (Abuodha and Kairo, 2001; AlonsoPerez et al., 2003; Barbier, 2003; Gunawardena and Rowan, 2005; Luers et al., 2006; Rakotomavo and Fromard, 2010; Paul and Vogl, 2011; Santos et al., 2014); and other activities such as river damming and herbicide use (Linden and Jernelov, 1980; Hong and San, 1993; Abuodha and Kairo, 2001; Koedam et al., 2007).

The management of forest resources needs to be based on mapping and inventory, along with the monitoring of natural or human-induced impacts over time. One of the most widely used methods to look into the recent past, and which will undoubtedly evolve into the single most important monitoring technology in the future is remote sensing (Dahdouh-Guebas and Koedam, 2008). Remote sensing and GIS has been widely used for the sustainable management of tropical coastal ecosystems (Dahdouh-Guebas, 2002; Neukermans et al., 2008; Satyanarayana et al., 2011; Nfotabong-Atheull et al., 2013) and integrated into transdisciplinary retrospective research on mangroves and other ecosystems (Dahdouh-Guebas and Koedam, 2008). Remote sensing and GIS assist in the continuous monitoring of forests and detect change that can be integrated into existing databases (Koedam et al., 2007). The results are valuable for the planning of mangrove management to improve their contribution towards natural resources, ecotourism and local livelihoods (DahdouhGuebas, 2002; Koedam et al., 2007).

Utilisation of mangrove resources and often consequent degradation has occurred in Vietnam for a long time (Hong and San, 1993; FAO, 2007). In the lower Mekong River Delta, several studies have applied remote sensing and GIS to detect changes of mangrove cover in relation to human impacts (NAS, 1974; Tong et al., 2004; Binh et al., 2005; Thu and Populus, 2007; Koedam et al., 2007; Lam-Dao et al., 2011; Hai-Hoa et al., 2013). However, time series of remotely sensed data was lacking before the Vietnam War (1962-1972), even though there was a major impact before that time (Ross, 1975; Stellman et al., 2003). In the Mui Ca Mau, there is a scarcity of data from the 1970s (Tong et al., 2004; Hai-Hoa et al., 2013) and 1990s (Tong et al., 2004; Koedam et al., 2007; Lam-Dao et al., 2011). The time intervals between the images studied plays an important role in detecting and quantifying the nature and timing of changes associated with anthropogenic impacts. More sampling dates help to facilitate clear goals for conservation, economic activities and coastal protection management by better identifying the timing and causes of major changes and by reconstituting baselines.

In this study, images from six occasions, from 1953 to 2011, were used to determine land cover changes in mangrove vegetation in the Mui Ca Mau, which were mostly caused by human impact. Remote sensing and GIS were applied. The approach is valuable for management planning to understand and improve the contribution of mangrove forests to the provision of ecosystem services and resources, local livelihood and global interest.

\section{Materials and methods}

\subsection{Study area}

Located at the southern tip of Vietnam on the Mekong River Delta, the Mui Ca Mau supported a substantial area of mangrove vegetation. It was originally the largest area and best developed mangrove vegetation in Vietnam (Hong and San, 1993). The study area is between $8^{\circ} 32^{\prime} \mathrm{N}$ to $8^{\circ} 49^{\prime} \mathrm{N}$ and $104^{\circ} 40^{\prime} \mathrm{E}$ to $105^{\circ} 19^{\prime} \mathrm{E}$ (Fig. 1 ). It covers all of Ngoc Hien District and part of Nam Can District of Ca Mau Province and was originally dominated by mangrove vegetation.

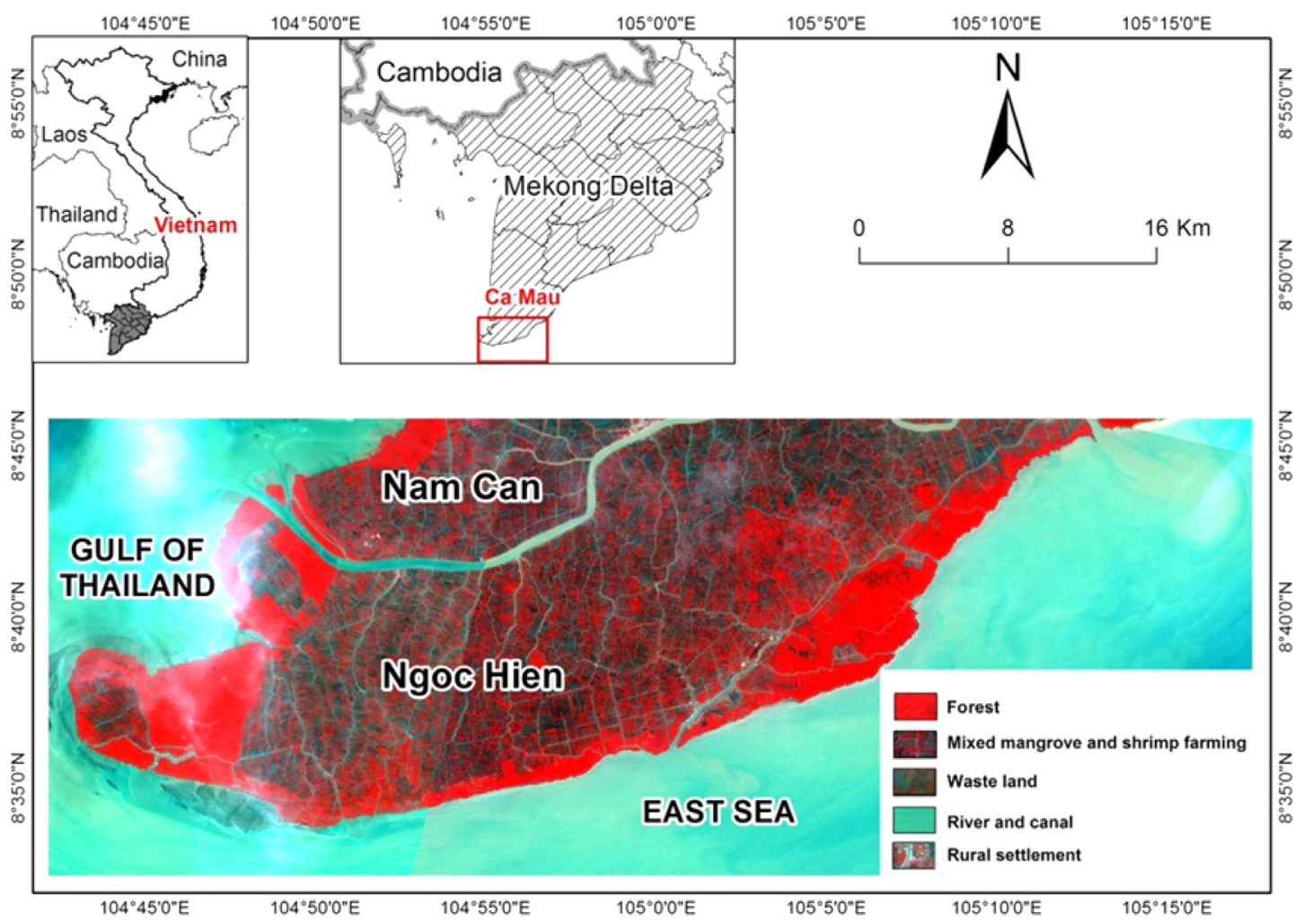

Fig. 1. Map of study area showing the location of the study area in Ca Mau Province of Vietnam. 
The major mangrove species are Avicennia alba Blume, Avicennia marina (Forssk.) Vierh., Avicennia officinalis L., Rhizophora apiculata Bl., Bruguiera parviflora Wight \& Arnold ex Griffith, Ceriops zippeliana Blume and Nypa fruticans (Thunb.) Wurmb. (Hung and Tan, 1999; Massó i Alemán et al., 2010). The natural ecosystem had a high conservation value for biodiversity and scenic beauty (MAB Vietnam, 2008). A large area of the Mui Ca Mau was designated a UNESCO International Biosphere Reserve in 2009 and 41,862 ha of the mangrove forest and shore at the Mui Ca Mau was declared as Mui Ca Mau National Park in 2003 and included as a Ramsar site in 2013.

Topographically, the study area is a low deltaic plain, strongly divided by a system of natural rivers and now a dense network of canals. The water flow regime in the large intertidal area is under the influence of the tidal disparity between the East Sea and the Gulf of Thailand, with dominant tidal flows from the eastern side. On the east coast, the tide is semi-diurnal with an average amplitude of $3 \mathrm{~m}$. On the Gulf of Thailand coast, the tidal regime is diurnal with amplitudes ranging from 0.5 to $0.8 \mathrm{~m}$. The whole area is characterized by soft muddy soils and some peat swamps (Hong and San, 1993).

\subsection{Data sources}

Aerial photographs from 1953 and remotely sensed image data of Landsat $(1975,1979)$ and SPOT $(1992,2004$ and 2011) were used to detect the changes in land cover in the study area (Table 1). The Landsat images were freely downloaded from the U.S. Geological Survey at level $1 \mathrm{~T}$ which is processed to standard terrain correction. Other images were purchased by the Laboratory of Plant Biology and Nature Management, Vrije Universiteit Brussel and the Vietnam Institute of Meteorology, Hydrology and Climate Change. The SPOTs were processed at the level of orthorectific using ground control points and a digital elevation model. Data were georeferenced to the UTM WGS-1984 Zone $48 \mathrm{~N}$ projection and coordinate system with further geometric correction using ENVI software.

Together with ground truth data (2006, 2010 and 2011), a vegetation map (1952) produced by the Service Géographique de l' Indochine at 1:100,000 scale, a topographic map (1980) at $1: 250,000$ scale and a digitized wetland map at $1: 100,000$ scale by the National Remote Sensing Center (2008-2009) were used as base maps for result validation.

\subsection{Data processing}

The grey scale aerial photographs of 1953 are at a scale of 1:50,000, with clear sky. Visual interpretation was done using a stereoscope. The map (after interpretation of land cover) was

Table 1

Specifications of the remotely sensed data used in this study.

\begin{tabular}{lllll}
\hline No. & Name & Path/row & Acquired date & Resolution $(\mathrm{m})$ \\
\hline 1 & Aerial photos & & $01 / 01 / 1953$ & 20 \\
2 & Landsat 2 MSS & $135 / 054$ & $22 / 11 / 1975$ & 79 \\
3 & Landsat 3 MSS & $135 / 054$ & $13 / 02 / 1979$ & 79 \\
4 & SPOT 2 & $273 / 332$ & $03 / 01 / 1992$ & 20 \\
5 & SPOT 2 & $273 / 333$ & $03 / 01 / 1992$ & 20 \\
6 & SPOT 2 & $274 / 333$ & $03 / 01 / 1992$ & 20 \\
7 & SPOT 5 & $273 / 332$ & $07 / 01 / 2004$ & 10 \\
8 & SPOT 5 & $273 / 333$ & $07 / 01 / 2004$ & 10 \\
9 & SPOT 5 & $274 / 333$ & $07 / 01 / 2004$ & 10 \\
10 & SPOT 5 & $273 / 332$ & $19 / 02 / 2011$ & 10 \\
11 & SPOT 5 & $273 / 333$ & $19 / 02 / 2011$ & 10 \\
12 & SPOT 5 & $274 / 333$ & $19 / 02 / 2011$ & 10 \\
\hline
\end{tabular}

scanned and digitized. Very small areas dominated by mangrove genera other than Rhizophora and Avicennia, such as Sonneratia, Nypa, Bruguiera or Ceriops were not distinguishable. Small areas of freshwater swamp or marshland and surface water were easily recognized by their colour (black).

ENVI and ArcGIS was used for Landsat/SPOT image processing and map manipulation. The band combination of 574, 754 and 321 were used respectively in LANDSAT/MSS 1975, 1979 and SPOT images. The image elements were analysed both by visual and digital interpretation. Firstly, a visual classification was applied to identify and to draw obviously homogeneous land cover units through interpretation keys (hue, texture, morphology, and contrast effects) and field exploration (ground truthing). This provisional classification was considered the basis for the next step of supervised digital classification.

The maximum likelihood method was used to obtain a supervised classification. Representative training areas were identified and a numerical description of the spectral attributes of each land cover type of interest in the scene was developed. Next, each parcel in the image data set was categorised into the land cover class it most closely resembled. The category label assigned to each parcel in this process was recorded in the corresponding cell of an interpreted data set. After the entire data set was categorised, the results were presented in the output state.

'Forest', 'shrimp monoculture' and 'mangrove-shrimp farm' were clearly delineated. Mangrove forests are usually well delineated from a simple visual interpretation of a colour composite based on image attributes such as colour, texture and structure (Dahdouh-Guebas et al., 2006b). The supervised classification was able to differentiate Rhizophora and Avicennia forest at low tidal level, where Avicennia forest gives less reflection or is darker than Rhizophora, and the pattern and texture of Avicennia is fine and smooth while Rhizophora forests have a coarse and heterogeneous surface.

In the field, a wide range of ground-truth information on mangrove conditions, density and species composition was collected. Mangrove forest cover in mangrove-shrimp farming systems were retrieved through household interviews and further validated by field observation. Integrated mangrove-shrimp quaculture is a silvo-fishery system that mixes shrimp ponds and mangroves on farms. Shrimp pond areas have a range of 3-10 ha and are surrounded by small dikes which control the water level and form a border with neighbouring shrimp farms. Within the ponds, the mangrove trees are typically planted in a row pattern, although some farms have remnant natural vegetation if they are cut from natural forests. Based on the regulations on mangrove area on farms (discussed in Section 4.1.2), ground truth data and the wide variation of mangrove versus pond area on farms since the 1990s, two categories were used for the mangrove-shrimp farm systems: $<50 \%$ versus $50-70 \%$ mangrove coverage on the farms.

The accuracy assessment was conducted for the 1953, 1979, 2004 and 2011 images, as there were no ground truth data or base maps for the years of 1975 and 1992. The Kappa coefficient applied here as an accuracy assessment was $0.80,0.73,0.69$ and 0.77 for the 1953, 1979, 2004 and 2011 images respectively. Meanwhile, the overall classification accuracy ranged from $77.5 \%$ to $83.5 \%$.

Eight land cover categories were identified:

1. Avicennia forest dominated by Avicennia spp., principally A. alba.

2. Rhizophora forest dominated by R. apiculata.

3. Mixed forest: dominated by a mixture of mangrove species like A. alba, R. apiculata, Bruguiera spp. and Ceriops spp. naturally develops from colonising Avicennia vegetation.

4. Intensive shrimp monoculture with no mangrove trees in or bordering aquaculture ponds. 


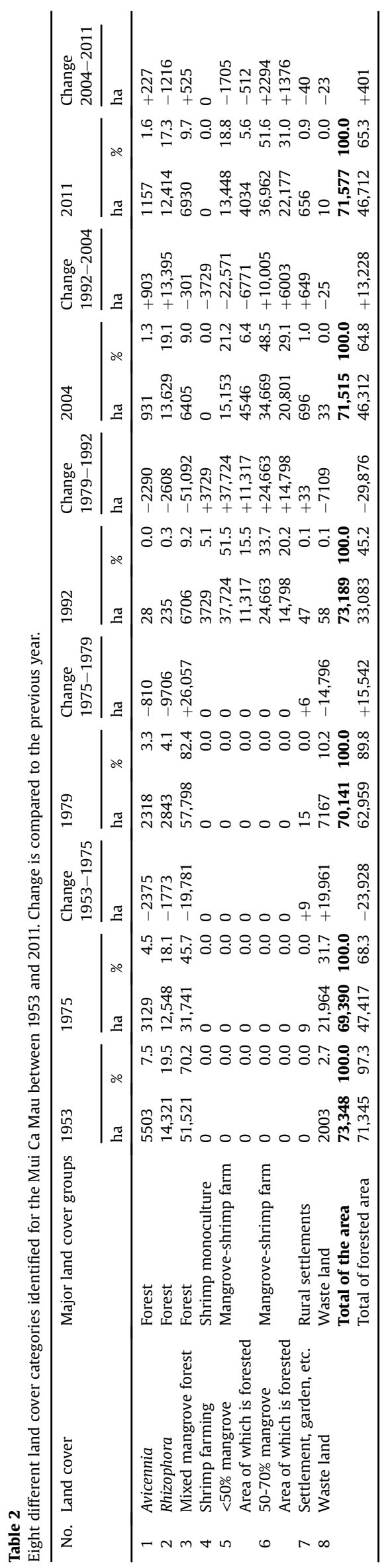

5. $<50 \%$ mangrove: mangrove-shrimp farm with $<50 \%$ mangrove cover in ponds and $>50 \%$ clear water surface.

6. 50-70\% mangrove: mangrove-shrimp farm with 50-70\% mangrove cover in ponds and 30-50\% clear water surface.

7. Rural settlements and gardens, including residential houses and adjoining fruit gardens.

8. Waste land: unvegetated land that was evidently unused at the time of study.

In order to enhance readability, the eight categories were grouped into five major land cover groups for mapping: forest (Avicennia, Rhizophora, and mixed forests), shrimp monoculture, mangrove-shrimp farm (both $<50 \%$ mangrove and $50-70 \%$ mangrove categories), rural settlements, and waste land. This is adaptable to published categories on Ca Mau Province by Binh et al. (2005) and Koedam et al. (2007).

\subsection{Spatio-temporal dynamics}

Finally, the spatio-temporal dynamics of the land cover were estimated and quantified. Special attention was given to the conversion of land into shrimp ponds and the floristic within the remaining mangrove areas. From this, a first set of recommendations for further monitoring of mangrove land cover change and the development of aquaculture and related activities and of their environmental impacts was generated.

\section{Results}

\subsection{Land cover}

Four recognizable land cover categories (Avicennia forest, $R$ hizophora forest, mixed forest and waste land) were present in 1953 (Table 2), grouped into two major categories of forest and waste land for illustration (Figs. 2 and 3). Forest covered 71,345 ha, accounting for more than $97 \%$ of the land area (Table 2). Avicennia forest was found in areas characterized by recent deposition of coastal alluvial material, but mixed forest vegetation covered the largest area (Fig. 2). Shrimp monoculture, mangrove-shrimp farming systems, and rural settlements were not observed at this time.

In 1975, five land cover categories (Avicennia forest, Rhizophora forest, mixed forest, rural settlement, and waste land) were present (Table 2). These were grouped into three major categories: forest, rural settlement and waste land for illustration (Figs. 2 and 3). Forest covered 47,417 ha or $68.3 \%$ of the total land cover, while waste land increased to $31.7 \%$ of the study area (Table 2 ). The waste land category largely corresponds to chemical warfare patterns. Shrimp monoculture and mangrove-shrimp farming systems were evident and probably did not yet exist. Con Trong Island was formed in the Cua Lon River estuary on the Gulf of Thailand between 1953 and 1975.

In 1979, the same five land cover categories were present as in 1975 (Table 2), in the same three major categories (Figs. 2 and 3). Forest covered 62,959 ha (about $90 \%$ of the total land area), a much higher figure and percentage than 1975, despite the short time between surveys. A total of 14,796 ha (about $20 \%$ of the study area) of waste land in 1975 was again covered by forest by 1979. Rural settlement and waste land covered 15 and 7167 ha respectively (Table 2). Shrimp monoculture and mangrove-shrimp farming systems were not yet apparent.

By 1992 all eight land cover categories were present (Table 2), grouped into five major categories for illustration (Figs. 2 and 3). Mangrove-shrimp farms were the major land use covering 62,387 ha ( $85.2 \%$ of the study area). Intensive shrimp monoculture 

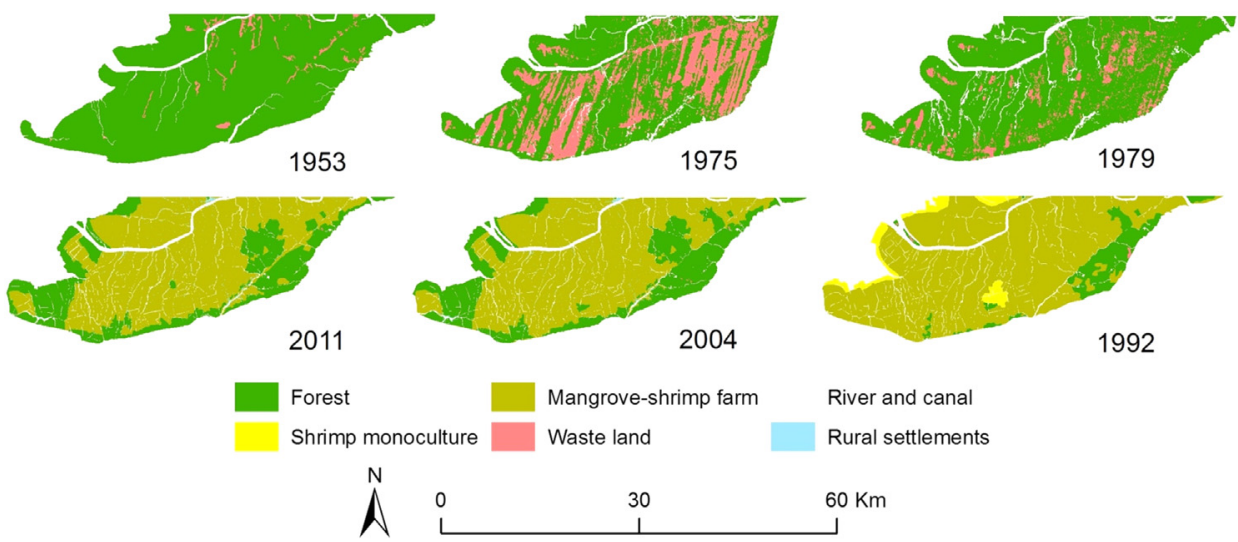

River and canal

Rural settlements $60 \mathrm{Km}$

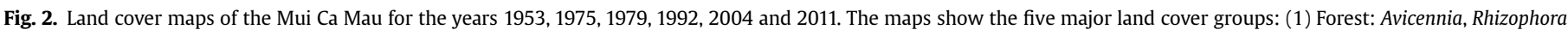
and mixed mangrove forests; (2) Shrimp monoculture; (3) Mangrove-shrimp farm; (4) Rural settlements; and (5) Waste land.

was observed mainly along the Gulf of Thailand and covered 3729 ha (5.1\%). Hence, shrimp farming covered almost $90 \%$ of the area while forest area declined to 6968 ha (9.5\%). Con Ngoai Island formed in the Cua Lon estuary to the northeast of Con Trong. Forest covered some of the new islands of Con Trong and Con Ngoai and small parts along the East Sea shore. Rural settlements were aligned along the rivers and canals.

In 2004, mangrove-shrimp farming systems were the major land cover, with an area of 49,822 ha (69.7\% of the study area) (Table 2, Figs. 2 and 3). Intensive shrimp monoculture was no longer observed. Forest area (principally Rhizophora) increased to 20,965 ha $(29.4 \%)$ along the coastlines of both the Gulf of Thailand and the East Sea. Rural settlements followed the rivers and canals.

In 2011, mangrove-shrimp farming systems covered 50,410 ha (70.4\% of the study area), a similar area to 2004 (Table 2, Figs. 2 and $3)$. Forest covered 20,501 ha (28.6\% of the study area) along the coastline of the Gulf of Thailand and the East Sea and had reappeared in the western part of Mui Ca Mau National Park. Intensive shrimp monoculture was not observed and settlements remained concentrated on rivers and canals.

\subsection{Land cover changes}

Notable changes in land cover occurred at the study area from 1953 to 2011 (Table 2, Figs. 2 and 3). The forest area declined

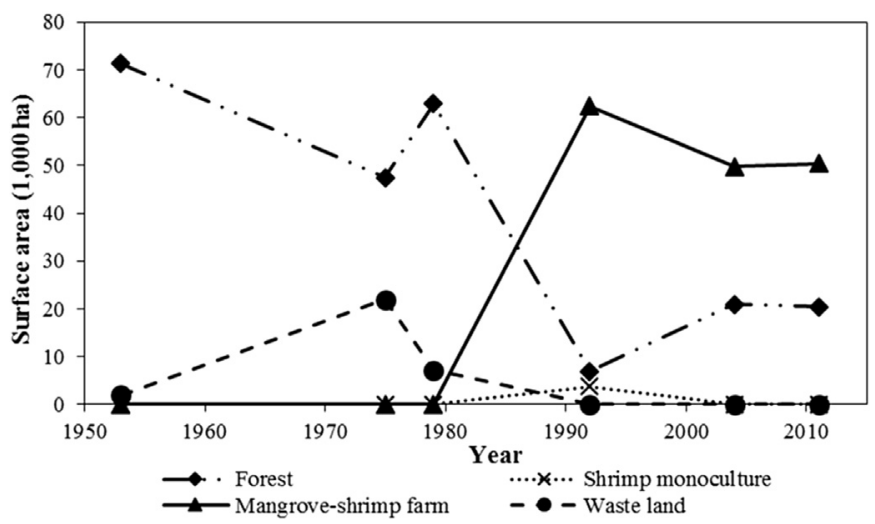

Fig. 3. Changes in land cover of four major land cover groups (forest, shrimp monoculture, mangrove-shrimp farm and waste land) between 1953 and 2011 in the Mui Ca Mau, Vietnam. drastically from 71,345 ha in 1953 to 6968 ha in 1992, then rose to 20,501 ha in 2011. The major loss has been in the natural mangrove forests. By far the greatest loss was in the natural mixed forest category which dominated the mangrove area in 1953, with major decline by conversion to aquaculture after 1979 (Table 2, Figs. 2 and 4). Between 1992 and 2004, planted Rhizophora forest become the largest mangrove forest type in the study area (Table 2 and Fig. 4) and continues to be so. The mixed mangrove forest has been quite stable in area since 1992, while the colonising Avicennia forests have slightly increased in depositional areas since 1992 (Table 2 and Fig. 2).

Aquaculture (intensive shrimp monoculture and mangroveshrimp farming systems) went from non-existent in 1979, to the dominant land cover in 1992 and persisted as such until 2011. Initially, the proportion of shrimp monoculture was nearly $10 \%$, but was largely replaced by planted mangrove-shrimp farms after the initial phase (Figs. 2 and 5). In 1992, the area of mangrove-shrimp farms with $<50 \%$ mangrove cover was larger than that with $50-70 \%$ mangrove cover, but since that time systems with $50-70 \%$ mangrove cover have become dominant (Table 2, Figs. 3 and 5), with mangrove 'thickening', mostly planted Rhizophora. The area of waste land noticeably increased from 2003 ha in 1953 to 21,964 ha in 1975 , reflecting war damage. Rural settlements increased greatly in proportion from 1975 to 2011, but the area covered of 656 ha in 2011 was relatively small.

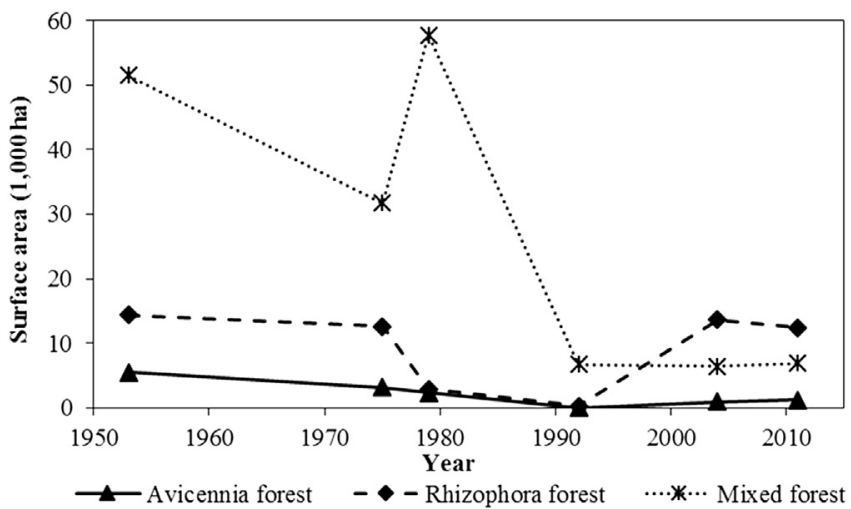

Fig. 4. Changes in the area of mangrove forests between 1953 and 2011 in the Mui Ca Mau, Vietnam. 


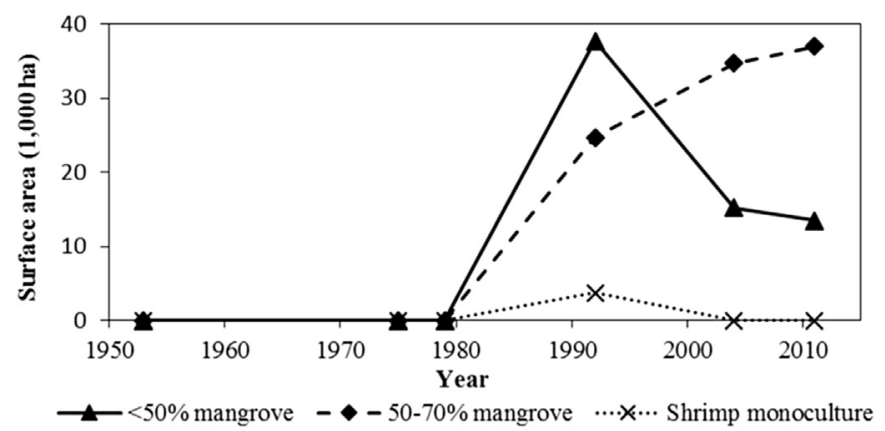

Fig. 5. Changes in the area of shrimp monoculture and mangrove-shrimp farm between 1953 and 2011 in the Mui Ca Mau, Vietnam.

\section{Discussion}

\subsection{Mangrove deforestation}

Mangrove forests covered more than $97 \%$ of the study area in the Mui Ca Mau in the early 1950s. Parts of the mangrove forest were degraded for charcoal and tannin production before 1928 when the French colonial administration introduced forest management including the replanting of 38,000 ha of degraded mangrove forest, usually with $R$. apiculata, which was the most economically important species (Moquillon, 1950; in NAS, 1974). This planting likely accounts for some of the area of Rhizophora-dominated mangrove forest in 1953. In addition, slow natural development of Avicennia cover may have favoured the prominence of Rhizophora in the canopy. Thus, it is possible that some natural forests with high cover of Rhizophora were mapped as Rhizophora rather than mixed forests.

Since then, large areas of mangrove forests have been destroyed and converted to other land-uses. We registered a minimum of forested area in 1992 (45\% of the study area; Table 2). The rate of loss in mangrove area in both natural forest stands and in mangrove-shrimp farms was about 53\% between 1953 and 1992, which is higher than the global (35\%) and Asian (36\%) estimates of decrease in mangrove area (Valiela et al., 2001). On an annual basis, it is also slightly higher than the estimated rate of loss of mangroves in Vietnam (of 62\% between 1945 and 1995; Turner et al., 1998).

The rate of loss of mangroves between 1979 and 2004 (26\% of the study area) was higher than a global estimate of $20 \%$ between 1980 and 2005 (Spalding et al., 2010). A small part of the decrease in mangrove cover is due to the fast and persistent erosion on the eastern coast of the Mui Ca Mau, with natural colonization and progression of mangroves on accreted sediments on the western side only compensating for part of the mangrove loss on the eastern side (Van Dam, 2010; Tran Thi et al., 2014).

Hydrological changes in the Mekong River and its delta (hydroelectric dams upstream and canals and their levees crisscrossing the delta and redirecting flows) are an extra factor of complexity in local dynamics of erosion versus sedimentation. Moreover, coastal mangrove ecosystems may be impacted by lower sediment loads (Lu and Siew, 2006) in the long-shore drift from the Mekong River mouths southwards towards Ca Mau (MAB Vietnam, 2008). Canals may direct the annual overland flows from the annual Mekong River flooding and their sediment loads to the coast in a more spatially limited way than is natural. However, to date the majority of the mangrove loss in the Mui Ca Mau is purely anthropogenic driven by war strategies and conversion of land into aquaculture. Reforestation programmes have compensated for some loss, but not with the natural suite of species.

\subsubsection{Herbicides from chemical warfare}

The forests under the study experienced significant damage during the Vietnam War from the application of herbicides and defoliants by the U.S. Air Force. As part of the war strategy (1962-1972), large tracts of forest, including mangrove forest, in the southern provinces of Vietnam were defoliated using herbicides to reveal military shelters and food supplies (Stellman et al., 2003). NAS (1974) estimated that 104,939 ha or $36 \%$ of the area of mangrove in southern Vietnam was subjected to one or more chemical attacks. Heavy defoliation not only devastated the vegetation, but also affected heterotrophs changing the whole ecosystem (Hong and San, 1993).

The Mui Ca Mau was one of the most heavily impacted regions by chemical warfare (Hong and San, 1993). From 1966 to 1970, it received high doses of herbicides and defoliants (Ross, 1975). The profound impact in the Mui Ca Mau is detected in this study by the large increase in bare waste land in 1975 over 1953. The pattern of impact has a similarity to the flight paths of spray missions (NAS, 1974; Stellman et al., 2003).

Using 1972 aerial photography, NAS (1974) states that 52\% of the Mui Ca Mau was then bare of mangrove trees, with $80 \%$ of the forest area being Rhizophora-dominated. The percentage of Rhizophoradominated forest in 1975 was lower than this in this study, perhaps suggesting differing categories of classification. The area of forest apparently lost from 1953 to1975 (Table 2) is less than that of NAS (1974) and Lam-Dao et al. (2011). However, there is a possible trend of mangrove area reestablishment, from approximately $48 \%$ of the respective study areas in 1972 (NAS, 1974), to 57\% in early 1973 (Lam-Dao et al., 2011), and 68.3\% in late 1975 (this study). It is likely natural or planted regeneration is showing, especially by 1975 . Avicennia and Rhizophora grow rapidly from seedlings in good habitat and can show up in remote sensed images within a few years, for example natural regeneration of Avicennia in good conditions in breached aquaculture ponds in less than 3 years after tidal flow was reinstated (Wilson, 2010).

NAS (1974) illustrates natural regeneration of Rhizophora and Bruguiera within $200 \mathrm{~m}$ of waterways, notably the large Cua Lon River, but lower natural regeneration elsewhere. Some of this natural regeneration, combined with some surviving Avicennia trees (large Avicennia may be more resistant to chemical impact) and some planting may have contributed to the large increase in 'mixed forests' found in this study between 1975 and 1979 (26,057 ha).

Natural mangrove regeneration diminishes with distance from propagule sources after catastrophic vegetation impact exposes large areas leaving open space and debris (even on the scale of tens of meters as observed in Can Gio, Vietnam after storm damage to Rhizophora and Avicennia; Wilson, pers. obs.). The poor regeneration away from watercourses was ascribed by NAS (1974) to debris remaining from dead trees constraining the large propagules of Rhizophora and Bruguiera from dispersing far from the river source. By October 1971, this debris was in advanced stages of decay, so any impedance was temporary (NAS, 1974).

Nam (1990, in Hong and San, 1993) ascribed uneven growth of young planted $R$. apiculata to lingering toxicity, but this is not supported by NAS (1974). However, large physical and chemical changes are to be expected when mangrove soils are exposed, and these, along with insolation and exposure, might have been a factor in some poor seedling growth. However, the planted restoration of tree cover was very rapid, although many patches of waste land remained in 1979 (Fig. 2). Natural forests did remain in 1975 and 1979 , but many of the forests in the affected areas were secondary growth or plantations at the end of the 1970s (FAO, 2007). This contrasts with the mostly mature forest affected by chemical 
warfare. The regrowth and mangrove plantation re-established since remains less developed.

\subsubsection{Conversion of mangrove land into aquaculture and agriculture}

Just like in some other countries there is a tension between the conservation of mangroves and the development of shrimp farming in Vietnam (cf. Dahdouh-Guebas et al., 2002). The Vietnamese government has encouraged shrimp farming for export since the early 1980s and it became a wide-spread activity. This was often at the expense of mangrove forests, especially in southern Vietnam (Hong and San, 1993). From 1980 until the late 1990s, there was rapid expansion in shrimp aquaculture throughout most of the coastal Mekong Delta, driven by economic liberalisation, high international prices, and active government promotion (Hong and San, 1993; Hashimoto, 2001). In addition, shrimp farming was promoted by international organizations such as the World Bank and the Asian Development Bank as a means to reduce poverty and create employment and income (Binh et al., 2005). Shrimp aquaculture increased by 3500\% between 1976 and 1992 in the whole Mekong Delta (Johnston et al., 2000). Expansion of aquaculture in the 1980s and 1990s resulted in the loss of about two-thirds of Vietnam's remaining mangroves by 2000 (IUCN, 2012).

In the study area, the loss of approximately 29,876 ha of mangrove (53\% of the study area) between 1979 and 1992 was largely due to conversion to aquaculture. In Asian countries such as Thailand, Indonesia, the Philippines and Vietnam, conversion to brackish water aquaculture is a major agent of mangrove change (Giesen et al., 2006). This study is consistent with numerous studies detailing serious impact of conversion to aquaculture on mangrove vegetation (Wolanski et al., 2000; Valiela et al., 2001). In Thailand approximately $50 \%-65 \%$ of mangroves have been lost to shrimp farm conversion since 1975 (Barbier, 2003) and in the Philippines about half of the 279,000 ha of mangroves lost from 1951 to 1988 was for aquaculture (Primavera, 2000).

Initially, extensive tidal areas in Ca Mau were converted for agriculture (Binh et al., 2005; Koedam et al., 2007). From 1976 to 1982, the former Minh Hai Province (now Ca Mau and Bac Lieu Provinces) reclaimed 26,300 ha of mangrove forest to grow soybean, rice and medicinal plants, of which 17,645 ha was in the former Ngoc Hien District (currently Nam Can and Ngoc Hien Districts) (Hong and San, 1993). Sam and Binh (1999) estimate 24,000 ha of mangroves were converted to agriculture between 1977 and 1983 in present day Ca Mau Province. Crops soon failed and the land was converted to aquaculture. The dramatic impact of conversion during the 1980s in the study area is shown by the fact aquaculture went from undetected in 1979 to covering 66,116 ha or about $90 \%$ of the study area in 1992 (Table 2 and Fig. 2). Mangroveshrimp farms with $<50 \%$ mangrove forest cover occupied 37,724 ha in 1992.

In 1991, Minh Hai Province issued regulations allowing farmers to use $<30 \%$ of allocated land (up to $10 \mathrm{ha}$ ) for aquaculture or agriculture but having to retain or establish $>70 \%$ mangrove cover in integrated mangrove-shrimp farming systems on their farms. Mangrove-shrimp farms were present in 1992, mostly with $<50 \%$ mangrove cover, but there were both further decline in monoculture shrimp systems and mangrove-shrimp farming systems with $<50 \%$ mangrove cover in favour of mangrove-shrimp systems with higher mangrove cover by 2004 under this administrative regime. The $30 \%$ water and $70 \%$ mangrove ratio was often not met in the study area during the time it was regulated. Mangroveshrimp farms remain the dominant land use, with virtually all the new mangrove cover in mangrove-shrimp farms being monoculture $R$. apiculata, because this species has the highest timber value and is easy to plant (Hong, 2003; Goessens et al., 2014).
In 2002, the provincial regulation on the minimum area of tree cover in mangrove-shrimp farming systems evolved to 70\% (for pond area greater than $5 \mathrm{ha}$ ), $60 \%$ (for pond area of $3 \mathrm{ha}-5 \mathrm{ha}$ ) and $50 \%$ (for pond area smaller than $3 \mathrm{ha}$ ) of the total area. Recently, Decision 19 (2010) of the Ca Mau Provincial People Committee promulgated that $60 \%$ of the area must to be conserved for mangroves. High income from shrimp farming encourages farmers to increase the area of aquaculture by illegally cutting mangroves (Binh et al., 1997; Minh et al., 2001; Tong et al., 2004; Lam-Dao et al., 2011; Vo et al., 2013) and poor management, such as maintaining the water level too high in the ponds, can also lead to mangrove death. Despite these pressures, the apparent mangrove cover in the aquaculture regions of the study area increased from 1992 to 2004 and 2004-2011, as evidenced by greater areas being mapped in higher mangrove coverage classes (Table 2).

Government regulations stipulated that aquaculture in a strip of land $2 \mathrm{~km}$ wide along the coast must be mangrove-shrimp farming systems (Nhuong et al., 2002), but shrimp monoculture farming still spread along the coastline of the Gulf of Thailand by 1992 (Fig. 2). Illegal full conversion was perhaps in mangrove areas which people considered unsuitable for mangrove-shrimp aquaculture (Nhuong et al., 2002). Sometimes, the conversion of mangrove forest into shrimp ponds was encouraged by local governmental agencies or army units (Hong and San, 1993). This land-use change conflicting with regulations has been observed also in other areas such as on the Indian subcontinent (Foell et al., 1999; Dahdouh-Guebas et al., 2006a). Land allocations were converted to shrimp farming without any further permission. In 1980s, most newly established forestry aquaculture enterprises in Ca Mau cleared mangrove forest for the expansion of shrimp farming area and this led to the further deterioration of mangrove forests (Hong and San, 1993). Conversion of mangrove forest specifically for aquaculture also occurred around 1990 (Thoi, pers. comm.).

\subsubsection{Land management policy}

After 1975, the Vietnamese government stipulated that land had to be equally distributed amongst citizens, with the State Planning Commission responsible for land use decisions and crop choice (Sanh et al., 1998). From 1981 to 1985, the Minh Hai Department of Forestry was given responsibility for 7789 ha of mangrove in Dat Mui and Vo Doi Communes and local authorities (Districts and Communes) were given responsibility for the remainder. In this period, about $30 \%$ of forest was managed at the commune level, and much forest with this land tenure was cleared for aquaculture and agriculture (Loc, 2013). From December 1986, economic renovation policies gave more opportunity for farmers to more or less develop their land, subject to local regulations.

In order to slow the rate of deforestation across the country, the central Vietnamese Government reformed the national law in 1991 to protect forests (Hong, 2000). The rate of destruction of mangroves decreased, but was not halted. This led to additional forest related decisions, including urgent measures for protection and development of forest areas (Decision 286/QD-TTG) and a plan to establish 5 million ha of forest across the country (Decision 661/ QD-TTG) (Binh et al., 2005).

Conversely, the Prime Minister issued National Decree 773-TTg in 1994 stipulating that open coastal areas and water bodies could be used for aquaculture (Hai-Hoa et al., 2013). Household contractors clearing the mangrove forests were not supposed to pay tax for the first 5 years (Hue and Scott, 2008). This policy encouraged shrimp farmers to clear more remaining mangrove forests for aquaculture activities.

Land use decisions are made at provincial level under the national framework, and local political decisions also encouraged farmers to concentrate on shrimp farming. Firstly, the Ca Mau 
coastal provincial aquaculture plan for the period 2000-2010 demanded an expansion in shrimp farm area and an intensification of shrimp aquaculture (Nhuong et al., 2002). Secondly, from 2000, farmers were encouraged to transform coastal saline rice fields to shrimp aquaculture (Government of Vietnam (2000)).

The contradictory regulatory environment and market pressure resulted in a rapid expansion of the shrimp area in Vietnam by 2001, especially in Ca Mau Province where 202,000 ha was recorded under for shrimp production, accounting for $47.1 \%$ and $42.2 \%$ of the total shrimp area in the southern provinces and Vietnam, respectively (Nhuong et al., 2002). Mangrove-shrimp farms became the preferred model in Ca Mau, given the participatory forestry impetus as well as wanting to foster aquaculture (Section 4.2), but this was not always the case elsewhere in Vietnam.

\subsection{Reforestation and natural regeneration}

There is a long history of mangrove planting in Ca Mau. After the planting efforts of the French colonial administration, the next large scale mangrove planting was in areas damaged by herbicide application after 1975 (Hong and San, 1993; Hashimoto, 2001). The effective scale of this effort contribute to increase of 15,542 ha of forest from 1975 to 1979 and the recovery of 19,961 ha of bare areas created during the war years by 1992. From 1975 to 1996, 148,705 ha mangrove was planted in Minh Hai Province (Hong, 2003).

Much of the planting has been $R$. apiculata in mangrove-shrimp farming systems for its ease and timber utility (Hong, 2003), but in some places, natural regeneration of trees has occurred and limited trials of other species have been undertaken. Central Vietnamese government programmes for mangrove management activities such as reforestation and conservation actions date to 1978 (Binh et al., 2005), but these had already commenced in Ca Mau, where replanting coincided with other conversion of mangrove forests for agriculture and aquaculture.

A rising number of population after 1975 led to concerns that the mangrove forests of the Mekong Delta would not be able to meet demands for timber and charcoal (Johnston et al., 1998), adding to the interest in participatory forest plantings. This, plus declining shrimp productivity linked to mangrove loss and as a measure to remediate abandoned and illegal pond areas, paved the way for the development of the dominant integrated mangroveshrimp farming systems, with the aim of both timber production and aquaculture.

Hence, a second large net increase in mangrove area of approximately 13,228 ha between 1992 and 2004 reflects predominantly planting, plus a limited amount of natural regeneration. All the detected shrimp monoculture area in 1992 was gone by 2004, replaced by mangrove-shrimp farms. Further, about 22,571 ha of mangrove-shrimp farms with $<50 \%$ mangrove area was replaced by mangrove-shrimp farms with $50 \%-70 \%$ mangroves in the same period (Table 2). These results reflect the afforestation efforts of the government in the early 1990s, when they planted nearly 53,000 ha in Ca Mau Province according to IUCN (2012).

The national forest establishment plan from 1998 under Decision 661 also provided motivation for coastal Mekong Delta provinces to maintain and establish mangrove cover to deliver their part in the national plan. As well, several foreign-funded projects to rehabilitate mangrove areas were established in Ca Mau during the 1990s under the Mekong Delta Master Plan (Benthem et al., 1999). For example, the World Bank Coastal Wetlands Protection and Development Programme planted 25,262 ha mangrove in Ca Mau Province (MAB Vietnam, 2008). Further, Giesen et al. (2006) reported a replanting programme of about 6600 ha of former mangrove areas in five State Forestry/Fisheries Enterprises.

The fact much of the planting in the aquaculture zones has been of $R$. apiculata means that mangrove-shrimp farming systems with $R$. apiculata accounts for the typical land use in the study area. In relatively small areas other mangrove species, such as Ceriops tagal or A. marina, are prominent when aquaculture ponds have been cut from natural forests. In limited places within the mangrove-shrimp aquaculture areas, natural regeneration has occurred, but this is limited over most of the area.

The Mui Ca Mau has suffered greatly in the loss of natural mangrove forest. For example, Avicennia forest, the natural colonizing vegetation on newly accreted land, was reduced to $21 \%$ of the 1953 figure in 2011, although there was recovery in the tiny area of 28 ha in 1992. Even with planting programmes and limited natural regeneration, the mangrove forest cover of the study area was only $29 \%$ of the 1953 figure in 2011. Although mangroves planted in monoculture qualify as 'mangrove' in national and international tallies, they may not have the development or full range of functions of natural mangrove forests for biodiversity and coastal protection (Hashimoto, 2001; IUCN, 2012). It might take years before planted forests become colonised by non-planted species (Bosire et al., 2003), and their faunistic composition, structural complexity and natural processes turn out to be restored (Bosire et al., 2004, 2005a, 2005b, 2006, 2008a). R. apiculata and Bruguiera sexangula reached $30 \mathrm{~m}$ tall in natural forests in optimal sites in the Dat Mui area (Hong and San, 1993), the planted systems may reach less than half that height. In addition, there is an intention to harvest much of the $R$. apiculata present in mangrove-shrimp farming systems in about a 10-12 year rotation, albeit to be replaced by new planting.

However, greater awareness of the natural values of mangrove forest is now apparent in Ca Mau Province, for example with the declaration of Mui Ca Mau National Park. This study shows the rapid regaining of mangrove forest cover in the restoration areas within the National Park, beginning in 2004. Former aquaculture ponds have been breached to allow natural processes to reestablish and natural regeneration is occurring. Some new natural mangrove vegetation on recently accreted land is present, especially on the islands at the mouth of the Cua Lon River, and it is recommended such areas be retained as strictly protected areas to allow natural processes to occur, given the limited opportunities in most of the former mangrove areas of the Mui Ca Mau. Questions and problems remain, however even for the limited places on the coast where accretion is occurring and in reserves, including the looming issues of sea level rise and sediment loss from the Mekong River.

By 1999, Vietnam had an estimated 155,290 ha of mangrove, of which 96,876 ha were planted in a number of reforestation programmes (Hong, 2003), showing both the historical forces of degradation in Vietnam, plus the willingness to undertake largescale planting programmes. Ecological restoration, rather than for utility, has become more common in recent times, but questions remain about how utility is applied to conservation plantings. In places, easy and understood species (notably $R$. apiculata in southern Vietnam) may still be used for restoration and in plantings to counter coastal erosion, rather than optimal species or species mixes.

There have been many failures in mangrove planting worldwide (Elster, 2000; Erftemeijer and Lewis, 1999; Lewis, 2005; IUCN, 2012). In Ca Mau, planting of $R$. apiculata in mangrove-shrimp farms is well understood, but ecological or coastal protection restoration on coastal areas is more risky, as it is potentially subject to failure through poor planning (Hashimoto, 2001). Restoration plans should first assess the cause of the loss of mangroves in an 
area, and then the reasons for the lack of natural recovery before planting with the right species (Bosire et al., 2008b). In places near propagule sources, re-establishing the sediment and tidal characteristics brings regeneration very rapidly and planting is not necessary, as can be widely observed in the Mekong Delta.

Coastal erosion control is becoming urgent in the Mui Ca Mau and elsewhere in the Mekong Delta (cf. Tran Thi et al., 2014), plus a greater interest in ecological restoration means more coastal mangrove planting is likely. In Vietnam, a key weakness has been the frequent planting of homogeneous species with little consideration for maintenance needs or coastal and sediment dynamics (IUCN, 2012). Historical studies can inform rehabilitation efforts by better understanding the local environment and the species naturally present (IUCN, 2012; Tran Thi et al., 2014). The participation of local communities should be part of designing a mangrove restoration project to increase the legitimacy of the project, but also to increase the likelihood of future sustainable use and compliance with protective measures (Ronnback et al., 2007).

In order to reduce indirect aquaculture impacts on mangrove, economic incentives and disincentives in the form of penalties or credits for effluent disposal, groundwater abstraction, chemical use, etc. may be more effective than regulatory approaches in inducing behavioural changes towards the environment and generating revenues to finance environmental policy programmes (VanHoutte, 1995). Green taxes and payment for ecological services models as adopted by Vietnam might apply to factors such as correcting water quality problems, and rehabilitating mangroves (Barraclough and Finger-Stich, 1996).

\subsection{Conclusions}

Notable changes in land cover occurred in the study area over the six decade study period (1953-2011) due to chemical warfare, overexploitation of the standing mangrove forest timber resources and the conversion of forest to agriculture and aquaculture encouraged by land management policies. The impact on natural mangrove forest ecosystems has been large.

Much of the regulatory framework has been contradictory in encouraging aquaculture production, but also then seeking mangrove tree cover in the Mui Ca Mau. Extensive reforestation programmes have increased tree cover in the productive landscape, but predominantly with the aim of timber production, rather than full restoration of ecosystem functions, goods and services. As a result, the dominant land use is now a mixed aquaculture and forestry systems, dominated by the most desirable timber species, although some enhanced protection of natural mangrove forest and ecologically focused restoration has recently been instituted in the Mui Ca Mau.

Mui Ca Mau is highly vulnerable to climate change and sea-level rise due to its deltaic situation. Therefore, historical changes of mangrove vegetation should be considered at the early step of the study on impacts of climate change and sea level rise on mangrove ecosystems. This will inform adaptation efforts by better understanding the local environment and the species naturally present.

\section{Acknowledgements}

This research was supported by the Vlaamse Interuniversitaire Raad, the Mangrove Ecosystem Research Centre (Hanoi National University of Education) and the Vietnam Institute of Meteorology, Hydrology and Climate Change in cooperation with Belgian Science Policy Office and the Vietnamese Ministry of Science and Technology project. We would like to thank Mr. Loc Le Minh for providing historical data on mangrove forests and shrimp farm. Further thank is given to the Mui Ca Mau National Park for all logistics support in the field. This paper was in part presented at the 6 -yearly international conference entitled 'Meeting on Mangrove ecology, functioning and Management (MMM3)' held in Sri Lanka (2-6 July 2012).

\section{References}

Abuodha, P.A.W., Kairo, J.G., 2001. Human-induced stresses on mangrove swamps along the Kenyan coast. Hydrobiologia 458, 255-265.

Alonso-Perez, F., Ruiz-Lunab, A., Turner, J., Berlanga-Roblesb, C.A., MitchelsonJacob, G., 2003. Land cover changes and impact of shrimp aquaculture on the landscape in the Ceuta coastal lagoon system, Sinaloa, Mexico. Ocean Coast. Manag. 46, 583-600.

Barbier, E.B., 2003. Habitat-fishery linkages and mangrove loss in Thailand. Contemp. Econ. Policy 21 (1), 59-77.

Barraclough, S., Finger-Stich, A., 1996. Some Ecological and Social Implications of Commercial Shrimp Farming in Asia. UNRISD Discussion Paper, No. 74. United Nations Research Institute for Social Development and World Wide Fund for Nature, Switzerland, p. 62.

Benthem, W., Lavieren, L.P. van, Verheugt, W.J.M., 1999. Mangrove rehabilitation in the coastal Mekong delta, Vietnam. In: Streever, W. (Ed.), An International Perspective on Wetland Rehabilitation. Kluwer Academic Publishers, The Netherlands, pp. 29-36.

Binh, C.T., Phillips, M.J., Demaine, H., 1997. Integrated shrimp-mangrove farming systems in the Mekong delta of Vietnam. Aquac. Res. 28, 599-610.

Binh, T.N.K.D., Vromant, N., Hung, N.T., Hens, L., Boon, E.K., 2005. Land cover changes between 1968 and 2003 in Cai Nuoc, Ca Mau peninsula, Vietnam. Environ. Dev. Sustain. 7, 519-536.

Bosire, J., Dahdouh-Guebas, F., Kairo, J.G., Koedam, N., 2003. Colonisation of nonplanted mangrove species into restored mangrove stands in Gazi Bay, Kenya. Aquat. Bot. 76 (4), 267-279.

Bosire, J.O., Dahdouh-Guebas, F., Kairo, J.G., Cannicci, S., Koedam, N., 2004. Spatial variations in macrobenthic fauna recolonisation in a tropical mangrove bay. Biodivers. Conservation 13 (6), 1059-1074.

Bosire, J.O., Dahdouh-Guebas, F., Kairo, J.G., Kazungu, J., Dehairs, F., Koedam, N., 2005a. Litter degradation and CN dynamics in reforested mangrove plantations at Gazi Bay, Kenya. Biol. Conserv, 126, 287-296.

Bosire, J.O., Kazungu, J., Koedam, N., Dahdouh-Guebas, F., 2005b. Predation on propagules regulates regeneration in a high-density reforested mangrove plantation. Mar. Ecol. Prog. Ser. 299, 149-155.

Bosire, J.O., Dahdouh-Guebas, F., Kairo, J.G., Wartel, S., Kazungu, J., Koedam, N., 2006. Success rates and recruited tree species and their contribution to the structural development of reforested mangrove stands. Mar. Ecol. Prog. Ser. 325, 85-91.

Bosire, J.O., Kairo, J.G., Kazungu, J., Koedam, N., Dahdouh-Guebas, F., 2008a. Spatial and temporal regeneration dynamics in Ceriops tagal (Perr.) C.B. Rob. (Rhizophoraceae) mangrove forests in Kenya. West. Indian Ocean J. Mar. Sci. 7 (1), 69-80.

Bosire, J., Dahdouh-Guebas, F., Walton, M., Crona, B., Lewis, R., Field, C., Kairo, J., Koedam, N., 2008b. Functionality of restored mangroves: a review. Aquat. Bot. 89 (2), 251-259.

Cannicci, S., Burrows, D., Fratini, S., Smith, T.J., Offenberg, J., Dahdouh-Guebas, F. 2008. Faunal impact on vegetation structure and ecosystem function in mangrove forests: a review. Aquat. Bot. 89 (2), 186-200.

Dahdouh-Guebas, F., 2002. The use of remote sensing and GIS in the sustainable management of tropical coastal ecosystems. Environ. Dev. Sustain. 4, 93-112.

Dahdouh-Guebas, F., Koedam, N., 2008. Long-term retrospection on mangrove development using transdisciplinary approaches: a review. Aquat. Bot. 89, 80-92.

Dahdouh-Guebas, F., Pulukkuttige, J.L., 2009. A bibliometrical review on pre- and post- tsunami assumptions and facts about mangroves and other coastal vegetation as protective buffers. Ruhuna J. Sci. 4, 28-50.

Dahdouh-Guebas, F., Zetterström, T., Rönnbäck, P., Troell, M., Wickramasinghe, A., Koedam, N., 2002. Recent changes in land-use in the pambala-chilaw lagoon complex (Sri Lanka) investigated using remote sensing and GIS: conservation of mangroves vs. development of shrimp farming. Environ. Dev. Sustain. 4 (2), $185-200$.

Dahdouh-Guebas, F., Collin, S., Lo Seen, D., Rönnbäck, P., Depommier, D., Ravishankar, T., Koedam, N., 2006a. Analysing ethnobotanical and fisheryrelated importance of mangroves of the East-Godavari delta (Andhra Pradesh, India) for conservation and management purposes. J. Ethnobiol. Ethnomedicine $2,24$.

Dahdouh-Guebas, F., Verheyden, A., Kairo, J.G., Jayatissa, L.P., Koedam, N., 2006b. Capacity building in tropical coastal resource monitoring in developing countries: a re-appreciation of the oldest remote sensing method. Int. J. Sustain. Dev. World Ecol. 13 (1), 62-76.

Di Nitto, D., Dahdouh-Guebas, F., Kairo, J.G. Decleir H., Koedam, N., 2008. Digital terrain modelling to investigate the effects of sea level rise on mangrove propagule establishment. Mar. Ecol. Prog. Ser. 356, 175-188.

Di Nitto, D., Neukermans, G., Koedam, N., Defever, H., Pattyn, F., Kairo, J.G., Dahdouh-Guebas, F., 2014. Mangroves facing climate change: landward migration potential in response to projected scenarios of sea level rise. Biogeosciences 11, 857-871. 
Duke, N.C., Meynecke, J.O., Dittmann, S., Ellison, A.M., Anger, K., Berger, U., Cannicci, S., Diele, K., Ewel, K.C., Field, C.D., Koedam, N., Lee, S.Y., Marchand, C., Nordhaus, I., Dahdouh-Guebas, F., 2007. A world without mangroves? Science $317,41-42$.

Elster, C., 2000. Reasons for reforestation success and failure with three mangrove species in Colombia. For. Ecol. Manag. 131, 201-214.

Erftemeijer, P.L.A., Lewis, R.R., 1999. Planting mangroves on intertidal mudflats: habitat restoration or habitat conversion?. In: Ecotone, VIIIth Seminar, Enhancing Coastal Ecosystem Restoration for the 21st Century, Ranong and Phuket, May 1999, 1-11.

FAO (Food and Agriculture Organization of the United Nations), 2007. Mangroves of Asia 1980-2005: Country Reports, Rome. Working Paper 137, p. 148.

Foell, J., Harrison, E., Stirrat, R.L., 1999. Participatory Approaches to Natural Resource Management - the Case of Coastal Zone Management in the Puttalam District, Summary Findings of DFID-funded Research "Participatory Mechanisms for Sustainable Development of Coastal Ecosystems" (Project R6977). School of African and Asian studies, University of Sussex, Falmer, Brighton, U.K, p. 48.

Giesen, W., Wulffraat, S., Zieren, M., Scholten, L., 2006. Mangrove Guidebook for Southeast Asia. FAO Regional Office for Asia and the Pacific, Bangkok, Thailand, p. 769.

Goessens, A., Satyanarayana, B., Van der Stocken, T., Quispe Zuniga, M., MohdLokman, H., Sulong, I., Dahdouh-Guebas, F., 2014. Is Matang mangrove forest in Malaysia sustainably rejuvenating after more than a century of conservation and harvesting management? PLoS One 9 (8), e105069.

Government of Vietnam, 2000. Resolution No. 09 Regarding Guidelines and Policies for Transforming Economic Structure and Consuming Agriculture Products. Hanoi, Vietnam.

Gunawardena, M., Rowan, J.S., 2005. Economic valuation of a mangrove ecosystem threatened by shrimp aquaculture in Sri Lanka. Environ. Manag. 36 (4), $535-550$.

Hashimoto, T.R., 2001. Environmental Issues and Recent Infrastructure Development in the Mekong Delta: Review, Analysis and Recommendations with Particular Reference to Large-scale Water Control Projects and the Development of Coastal Areas. University of Sydney, Australia, p. 70. Working Paper No. 4.

Hai-Hoa, N., McAlpine, C., Pullar, D., Johansen, K., Duke, N.C., 2013. The relationship of spatial - temporal changes in fringe mangrove extent and adjacent land-use: case study of Kien Giang coast, Vietnam. Ocean Coast. Manag. 76, 12-22.

Hong, P.N., 2000. Effects of mangrove restoration and conservation on the biodiversity and environment in Can Gio district. In: Mangrove Management and Conservation Workshop, Okinawa, Japan, 2004, pp. 111-137.

Hong, P.N., 2003. Mangrove forests in Vietnam - present status and challenges. In: International Symposium on Conservation and Wise Use of Mangroves in Southeast Asia, Brunei Darussalam, 6-8 October 2003.

Hong, P.N., San, H.T., 1993. Mangroves of Vietnam. IUCN, Bangkok, Thailand.

Hue, L.T.V., Scott, S., 2008. Coastal livelihood transitions: socio-economic consequences of changing mangrove forest management and land allocation in a commune of central Vietnam. Geogr. Res. 46 (1), 62-73.

Hung, H.Q., Tan, D.T., 1999. Plants in Ca Mau Wetland. Department of Science, Technology and Environment, Ca Mau, Vietnam, p. 170.

IUCN (International Union for Conservation of Nature), 2012. Viet Nam national Strategy and Action Plan (2011-2013). Mangroves for the Future, Gland, Switzerland, p. 32.

Johnston, D., Clough, B., Xuan, T.T., Phillips, M., 1998. Mixed shrimp farmingmangrove forestry systems in the lower Mekong delta of Vietnam: overview and recommendations. In: Tce-project Workshop No. II: Coastal Environmental Improvement in Mangrove/wetland Ecosystems, Ranong, Thailand, 18-23 August 1998.

Johnston, D., Trong, N.V., Tien, D.V., Xuan, T.T., 2000. Shrimp yields and harvest characteristics of mixed shrimp-mangrove forestry farms in Ca Mau Province: factors affecting production. Aquaculture 188, 263-284.

Kathiresan, K., 2012. Importance of mangrove ecosystem. Int. J. Mar. Sci. 2 (10), 70-89.

Koedam, N., Dahdouh-Guebas, F., Monbaliu, D., Merken, R., Ruyck, J. De, Minh, V.Q., 2007. Improvement of Shrimp Production Sustainability and Shrimp Safety in Vietnam. Vrije Universiteit Brussel, Brussels, Belgium, p. 88. BelSPO Project Report.

Lam-Dao, N., Pham-Bach, V., Nguyen-Thanh, M., Pham-Thi, M.T., Hoang-Phi, P., 2011. Change detection of land use and riverbank in Mekong delta, Vietnam using time series remotely sensed data. J. Resour. Ecol. 2 (4), 370-374.

Lee, S.Y., Primavera, J.H., Dahdouh-Guebas, F., McKee, K., Bosire, J.O., Cannicci, S., Diele, K., Fromard, F., Koedam, N., Marchand, C., Mendelssohn, I., Mukherjee, N., Record, S., 2014. Ecological role and services of tropical mangrove ecosystems: a reassessment. Glob. Ecol. Biogeogr. 23 (7), 726-743.

Lewis, R.R., 2005. Ecological engineering for successful management and restoration of mangrove forests. Ecol. Eng. 24, 403-418.

Linden, O., Jernelov, A., 1980. The mangrove swamps: an ecosystem in danger. Ambio 9, 81-88.

Loc, L.M., 2013. Forest changes in Ca Mau Province (Vietnam) from 1975 to 2008. Technical Report. Ca Mau Forestry Department, Ca Mau city, Vietnam, p. 7.

Lu, X.X., Siew, R.Y., 2006. Water discharge and sediment flux changes over the past decades in the lower Mekong River: possible impacts of the Chinese dams. Hydrology Earth Syst. Sci. 10, 181-195.

Luers, A.L., Naylor, R.L., Matson, P.A., 2006. A case study of land reform and coastal land transformation in southern Sonora, Mexico. Land Use Policy 23, 436-447.
MAB Vietnam (Man and the Biosphere Programme), 2008. Mui Ca Mau Biosphere Reserve, Ca Mau Province. Biosphere Reserve Nomination Form to be submitted to UNESCO, p. 112.

Marshall, N., 1994. Mangrove conservation in relation to overall environmental consideration. Hydrobiologia 285, 303-309.

Massó i Alemán, S., Bourgeois, C., Appeltans, W., Vanhoorne, B., De Hauwere, N., Stoffelen, P., Heaghebaert, A., Dahdouh-Guebas, F., 2010. The 'Mangrove reference database and Herbarium'. Plant Ecol. Evol. 143 (2), 225-232.

Mazda, Y., Magi, M., Kogo, M., Hong, P.N., 1997. Mangroves as a coastal protection from waves in the Tong King delta, Vietnam. Mangroves Salt Marshes 1, $127-135$.

Mazda, Y., Magi, M., Nanao, H., Kogo, M., Miyagi, T., Kanazawa, N., Kobashi, D., 2002. Coastal erosion due to long-term human impact on mangrove forests. Wetl. Ecol. Manag. 10, 1-9.

Minh, T.H., Yakupitiyage, A., Macintosh, D.J., 2001. Management of the Integrated Mangrove Aquaculture Farming Systems in the Mekong Delta of Vietnam. ITCZM Monograph No. 1, p. 24.

Mukherjee, N., Dahdouh-Guebas, F., Kapoor, V., Arthur, R., Koedam, N., Sridhar, A., Shanker, K., 2010. From bathymetry to bioshields: a review of post-tsunami ecological research in India and its implications for policy. Environ. Manag. 46 (3), 329-339.

Nagelkerken, I., Blaber, S.J.M., Bouillon, S., Green, P., Haywood, M., Kirton, L.G. Meynecke, J.-O., Pawlik, J., Penrose, H.M., Sasekumar, a., Somerfield, P.J., 2008. The habitat function of mangroves for terrestrial and marine fauna: a review. Aquat. Bot. 89 (2), 155-185.

(NAS) National Academy of Sciences, 1974. The Effects of Herbicides in South Vietnam, Part a - Summary and Conclusions. National Academy of Sciences, Washington.

Neukermans, G., Dahdouh-Guebas, F., Kairo, J.G., Koedam, N., 2008. Mangrove species and stand mapping in Gazi bay (Kenya) using quickbird satellite imagery. J. Spatial Sci. 53 (1), 75-86.

Nfotabong-Atheull, A., Din, N., Dahdouh-Guebas, F., 2013. Qualitative and quantitative characterization of mangrove vegetation structure and dynamics in a peri-urban setting of Douala (Cameroon): an approach using air-borne imagery. Estuaries Coasts 36 (6), 1181-1192.

Nfotabong-Atheull, A., Din, N., Longonje, S.N., Koedam, N., Dahdouh-Guebas, F., 2009. Commercial activities and subsistence utilization of mangrove forests around the Wouri estuary and the Douala-Edea reserve (Cameroon). J. Ethnobiol. Ethnomedicine 5, 35.

Nhuong, T.V., Luu, L.T., Tu, T.Q., Tam, P.M., Nguyet, T.T.A., 2002. Vietnam Shrimp Farming Review. Research Institute for Aquaculture RIA-1, Bac Ninh province, Vietnam, p. 19. Partner Report for the Project: Policy research for sustainable shrimp farming in Asia.

Ong, J.E., 1982. Mangroves and aquaculture in Malaysia. Ambio 11, 252-257.

Paul, B.G., Vogl, C.R., 2011. Impacts of shrimp farming in Bangladesh: challenges and alternatives. Ocean Coast. Manag. 54 (3), 201-211.

Primavera, J.H., 2000. Development and conservation of Philippine mangroves: institutional issues. Ecol. Econ. 35 (1), 91-106.

Rakotomavo, A., Fromard, F., 2010. Dynamics of mangrove forests in the Mangoky River delta, Madagascar, under the influence of natural and human factors. For Ecol. Manag. 259, 1161-1169.

Rivera-Monroy, V.H., Twilley, R.R., 1996. The relative role of denitrification and immobilization in the fate of inorganic nitrogen in mangrove sediments. Limnol. Oceanogr. 41, 284-296.

Ronnback, P., Crona, I., Ingwall, L., 2007. The return of ecosystem goods and services in replanted mangrove forests: perspectives from local communities. Environ. Conserv. 4, 313-324.

Ross, P., 1975. The mangrove of southern Vietnam: the impact of military use of herbicides. In: Proceedings of International Symposium on Biological and Management of Mangroves, Hololulu, pp. 695-707.

Sam, D.D., Binh, N.N., 1999. Evaluation of Potential Use of Forest Land in the Mekong River Delta. Agriculture Publishing House, Hanoi, p. 104.

Sanh, N.V., Xuan, V.T., Phong, T.A., 1998. History and future of farming systems in the Mekong delta. In: Xuan, V.T., Matsui, S. (Eds.), Development of Farming Systems in the Mekong Delta of Vietnam, pp. 16-80. Ho Chi Minh City, Vietnam.

Santos, L.C.M., Reis Matos, H., Schaeffer-Novelli, Y., Cunha-Lignon, M., Dantas Bitencourt, M., Koedam, N., Dahdouh-Guebas, F., 2014. Anthropogenic activities in mangrove areas (São Francisco River Estuary, Brazil Northeast): a GIS-based analysis of CBERS and SPOT images to aid in local management. Ocean Coast. Manag. 89, 39-50.

Satyanarayana, B., Mohamad, K.A., Idris, I.F., Husain, M.L., Dahdouh-Guebas, F., 2011. Assessment of mangrove vegetation based on remote sensing and ground-truth measurements at Tumpat, Kelantan delta, East Coast of Peninsular Malaysia. Int. J. Remote Sens. 32 (6), 1635-1650.

Semesi, A.K., Howell, K., 1992. The Mangroves of the Eastern African Region. UNEP, p. $45,92-807-1348-5$.

Spalding, M., Kainuma, M., Collins, L., 2010. World Atlas of Mangroves. Earthscan, UK and USA, p. 319.

Stellman, J.M., Stellman, S.D., Christian, R., Weber, T., Tomasallo, C., 2003. The extent and patterns of usage of agent Orange and other herbicides in Vietnam. Nature 422, 681-687.

Tam, N.F.Y., Wong, Y.S., 1999. Mangrove soils in removing pollutants from municipal wastewater of different salinities. J. Environ. Qual. 28, 556-564.

Thu, P.M., Populus, J., 2007. Status and changes of mangrove forest in Mekong delta: case study in Tra Vinh, Vietnam. Estuar. Coast. Shelf Sci. 71, 98-109. 
Tong, P.H.S., Auda, Y., Populus, J., Aizpuru, M., Habshi, A. Al, Blasco, F., 2004 Assessment from space of mangroves evolution in the Mekong delta, in relation to extensive shrimp farming. Int. J. Remote Sens. 25 (21), 4795-4812.

Tran Thi, V., Tien Thi Xuan, A., Phan Nguyen, H., Dahdouh-Guebas, F., Koedam, N. 2014. Application of remote sensing and GIS for detection of long-term mangrove shoreline changes in Mui Ca Mau, Vietnam. Biogeosciences 11, $3781-3795$.

Turner, R.K., Adger, W.N., Lorenzoni, I., 1998. Towards Integrated Modelling and Analysis in Coastal Zones: Principles and Practices. Land-Ocean Interactions in the Coastal Zone Project, Texel (Netherlands). Reports and Studies no. 11.

Valiela, I., Bowen, J.L., York, J.K., 2001. Mangrove forests: one of the world's threatened major tropical environments. BioScience 51 (10), 807-815.

Van Dam, T., 2010. Potential Impacts of Climate Change Induced Sea Level Rise on Mangroves in Ca Mau, South Vietnam: Application of Remote Sensing
Techniques for Assessment (M.S. thesis). Vrije Universiteit Brussel, Belgium, p. 95.

Van-Houtte, A., 1995. Fundamental techniques of environmental law and aquaculture law. In: FAO/NACA Regional Study and Workshop on the Environmental Assessment and Management of Aquaculture Development, Network of Aquaculture Centres in Asia-Pacific, Bangkok, Thailand. TCP/RAS/2253.

Vo, Q., Oppelt, N., Leinenkugel, P., Kuenzer, C., 2013. Remote sensing in mapping mangrove ecosystems-an object-based approach. Remote Sens. 5 (1), 183-201.

Wilson, N., 2010. Biomass and Regeneration of Mangrove Vegetation in Kien Giang Province, Vietnam. Report to GTZ, p. 53.

Wolanski, E., Spagnol, S., Thomas, S., Moore, K., Alongi, M.D., Trott, L., Davidson, A., 2000. Modelling and visualizing the fate of shrimp pond effluent in a mangrove-fringed tidal creek. Estuar. Coast. Shelf Sci. 50, 85-97. 